\title{
Wpływ smarowego oleju silnikowego na powstawanie przedwczesnego zapłonu w silniku o zapłonie iskrowym podczas pracy w zakresie małej prędkości obrotowej
}

\author{
The impact of engine lubricating oil on the occurrence of Low Speed Pre-Ignition in \\ turbocharged GDI engines
}

\author{
Zbigniew Stępień \\ Instytut Nafty i Gazu - Państwowy Instytut Badawczy
}

\begin{abstract}
STRESZCZENIE: W nowoczesnych, doładowanych silnikach z zapłonem iskrowym i bezpośrednim wtryskiem paliwa zwiększanie ciśnienia powietrza w układzie dolotowym jest sposobem na podwyższenie sprawności silnika i jego osiągów, ale także na optymalizację procesu spalania i zmniejszenie emisji $\mathrm{CO}_{2}$. Jednak wysokie doładowanie silników i zmniejszanie ich objętości skokowej powoduje pojawienie się problemów związanych z różnymi rodzajami nienormalnego spalania, wśród których wyróżnia się LSPI (low speed pre-ignition) - przedwczesny zapłon w zakresie małej prędkości obrotowej i dużych obciążeń silnika. Występowanie LSPI może prowadzić do poważnych uszkodzeń silnika, w tym między innymi do: pęknięcia tłoków, wygięcia korbowodów oraz innych zniszczeń elementów wewnętrznych silnika. W artykule opisano różnice pomiędzy przedwczesnym zapłonem LSPI oraz zjawiskami typowego spalania stukowego oraz tzw. superstuku. Wyjaśniono, że spalanie stukowe oraz LSPI są odrębnymi zjawiskami, różniącymi się mechanizmami powstawania. Opisano skomplikowany mechanizm powstawania LSPI. Wyjaśniono, dlaczego w przeciwieństwie do konwencjonalnego spalania stukowego występowanie LSPI jest zjawiskiem nieprzewidywalnym i nie można mu zapobiegać poprzez regulację kąta wyprzedzenia zapłonu i zwiększenie liczby oktanowej benzyny. Wyniki dotychczas przeprowadzonych badań dowodzą, że prawdopodobnie główną przyczyną występowania LSPI jest samozapłon kropelek silnikowego oleju smarowego w komorach spalania silnika. Jednak wskazują też na wiele czynników, które mogą powodować LSPI w tym: konstrukcję silnika, warunki jego pracy, a także kompozycję silnikowego oleju smarowego i paliwa. W przypadku silnikowego oleju smarowego największy wpływ na LSPI ma skład chemiczny dodatków detergentowych. W mniejszym stopniu także inne dodatki uszlachetniające i skład silnikowego oleju smarowego mogą wpływać na LSPI. Baza olejowa ma też wpływ, chociaż mniejszy, na LSPI. Ma tu znaczenie zarówno jakość bazy olejowej, jak i jej lepkość. Przedyskutowane w artykule wyniki sugerują, że opracowanie odpowiedniej formulacji smarowego oleju silnikowego może przyczynić się do ograniczenia występowania zjawiska LSPI. Jednak sama optymalizacja składu silnikowego oleju smarowego nie doprowadzi do całkowitego wyeliminowania zjawiska LSPI.
\end{abstract}

Słowa kluczowe: downsizing silników, przedwczesny zapłon w zakresie małej prędkości obrotowej silnika, superstuk, ograniczenie emisji $\mathrm{CO}_{2}$, silnikowy olej smarowy.

ABSTRACT: In modern DISI (Direct Injected Spark Ignited) and supercharged engines, increasing the intake pressure is a way to achieve better performance, better fuel economy and, consequently, lower $\mathrm{CO}_{2}$ emission. However, boosted DISI and downsized engines are suffering from a series of abnormal combustion problems of which the LSPI (Low Speed Pre-Ignition) is an important part. LSPI can lead to potential serious damage of the engine (e.g. broken pistons, bent connecting rods or severe engine failure). The article describes the difference between pre-ignition, LSPI, knocking and super-knocking. Knocking and LSPI are two distinct events, caused by two different phenomena. The complex mechanism occurring in LSPI has been outlined. It explains why, unlike conventional knocking, an LSPI event cannot be predicted and corrected by adjusting spark timing or increasing the octane number. More current research suggest that the auto-ignition of oil droplets is probably the major cause of LSPI. However, many factors can cause LSPI, including: engine design, engine operating conditions as well lubricant and fuel composition. With regard to engine lubricating oil, the most noticeable impact has been from detergent chemistry. Aside from the detergent system, there are many other additive and lubricant compositions that can affect LSPI. Furthermore, base oils also affect LSPI events. Both the quality of the base stock and the viscosity can have secondary effects on LSPI. The discussed results suggest that appropriate engine lubricating oil formulations may enable the mitigation of LSPI. However, the complete elimination of LSPI will hardly be achieved by modifying only the oil properties.

Key words: engine downsizing, Low Speed Pre-Ignition, super-knock, $\mathrm{CO}_{2}$ reduction, engine lubricating oil.

Autor do korespondencji: Z. Stępień, e-mail: zbigniew.stepien@inig.pl

Artykuł nadesłano do Redakcji 28.06.2019 r. Zatwierdzono do druku 27.11.2019 r. 


\section{Wstęp}

Systematycznie zaostrzane przepisy w zakresie zmniejszania emisji szkodliwych składników spalin do atmosfery, a w szczególności ograniczenia emisji $\mathrm{CO}_{2}$, w połączeniu z wymaganiami rynkowymi wymuszają na producentach silników samochodowych działania w zakresie zmniejszenia zużycia paliwa przy zachowaniu osiągów silników. Od 2021 r. w Europie będzie wprowadzone dalsze ograniczenie emisji $\mathrm{CO}_{2}$, do wielkości $95 \mathrm{~g} / \mathrm{km}$ (średnia dla całej floty samochodów osobowych produkowanych przez danego producenta), której pomiar początkowo był odnoszony do cyklu pomiarowego NEDC (New European Driving Cycle). Jednakże wprowadzony od 1 września 2018 r. w miejsce NEDC nowy, znacznie bardziej wymagający i zbliżony do rzeczywistych warunków eksploatacji cykl pomiarowy WLTP (Worldwide Harmonised Light Vehicle Test Procedure) jeszcze bardziej utrudni producentom pojazdów dostosowanie się do tej wielkości emisji. Przyszłe cele UE zakładają dalsze ograniczenie emisji $\mathrm{CO}_{2}$ o kolejne $15 \%$ od roku 2025 i o $37,5 \%$ od roku $2030 \mathrm{w}$ odniesieniu do $95 \mathrm{~g} / \mathrm{km}$.

Aby spełnić powyższe wymagania, już od kilkunastu lat jednym $\mathrm{z}$ dominujących kierunków w zakresie rozwoju silników jest tzw. downsizing w połączeniu z downspeedingiem (Fraser et al., 2009; Shahed i Bauer, 2009; Turner et al., 2014). Kierunek ten zakłada poprawę sprawności ogólnej silników poprzez zmniejszenie objętości skokowej, zmniejszenie strat mechanicznych, m.in. poprzez zmniejszenie liczby i wielkości cylindrów oraz zmniejszenie liczby elementów obsługujących je układów (np. układ rozrządu), zmniejszenie strat na pompowanie oraz prędkości obrotowej silnika przy zwiększaniu wielkości momentu obrotowego silnika, zwłaszcza w zakresie małej prędkości obrotowej. To wszystko przy zachowaniu lub zwiększeniu osiągów silników. W konsekwencji w silnikach ZI (zapłon iskrowy) rozpowszechnił się bezpośredni wtrysk paliwa oraz doładowanie, $w$ tym przede wszystkim, turbodoładowanie. Jako przykład znacznych zmian osiągów, jakie to spowodowało na przestrzeni ostatnich 50 lat, można podać porównanie dwóch silników firmy Mercedes-Benz. W latach 70. XX wieku 8-cylindrowy silnik Mercedes W116 o objętości skokowej $6,9 \mathrm{dm}^{3}$, rozwijał moc maksymalną $212 \mathrm{~kW}$, a maksymalny moment obrotowy wynosił $550 \mathrm{Nm}$. Najnowszy 4-cylindrowy silnik Mercedes M139 o objętości skokowej 2,0 dm rozwija moc maksymalną $312 \mathrm{~kW}$ i ma maksymalny moment obrotowy $500 \mathrm{Nm}$.

W opisanych wyżej nowoczesnych konstrukcjach silników z ZI doładowanie, czyli zwiększanie ciśnienia, ładunku powietrza doprowadzanego do komór spalania służy nie tylko poprawie osiągów silników, ale przede wszystkim zwiększaniu ich sprawności, a zatem zmniejszaniu zużycia paliwa. Niestety ten sposób poprawy osiągów jest ograniczany poprzez zjawisko spalania stukowego, powstające na skutek samozapłonu części mieszanki paliwowo-powietrznej już po zapłonie iskrą świecy zapłonowej, ale w części komory spalania poza zasięgiem iskry zapłonowej. Zjawisko to zagraża trwałości silnika na skutek znacznego, gwałtownego zwiększenia ciśnienia spalania. Stosowane są różne metody zapobiegania spalaniu stukowemu, w tym: chłodzenie gazów recyrkulacji spalin, bezpośredni wtrysk paliwa, podział wtryskiwanego paliwa na części czy też zmienne fazy rozrządu. Tego rodzaju proces spalania stukowego jest związany z konstrukcją silnika, warunkami jego pracy i właściwościami paliwa (w tym przypadku benzyny). Jednak jeśli proces spalania zostanie zainicjowany w cylindrze przed wystąpieniem zapłonu iskrą świecy zapłonowej, mamy do czynienia ze zjawiskiem tzw. przedwczesnego zapłonu. W takim przypadku zapłon mieszanki występuje w centralnej części komory spalania w czasie zbliżonym do GMP (górnego martwego położenia) tłoka i następuje gwałtowny skok ciśnienia spalania, co prowadzi do zjawiska tzw. superstuku (rys. 1). Samozapłon obejmuje znacznie większą ilość mieszanki paliwowo-powietrznej aniżeli w przypadku typowego spalania stukowego. Gwałtowne skoki ciśnienia w przypadku superstuku niekiedy przekraczają 200 bar, podczas gdy w klasycznym spalaniu stukowym rzadko osiągają wartość 100 bar. Zjawisko superstuku jest charakterystyczne dla tzw. LSPI (low speed pre-ignition), przedwczesnego zapłonu w zakresie małych prędkości obrotowych silników doładowanych - rys. 2 (Dahnz i Spicher, 2010; Zahdeh et al., 2011; Wang et al., 2015). Superstuk w krótkim czasie może doprowadzić do zupełnego zniszczenia silnika, a w szczególności tłoków, pierścieni tłokowych, korbowodów, zaworów itp.

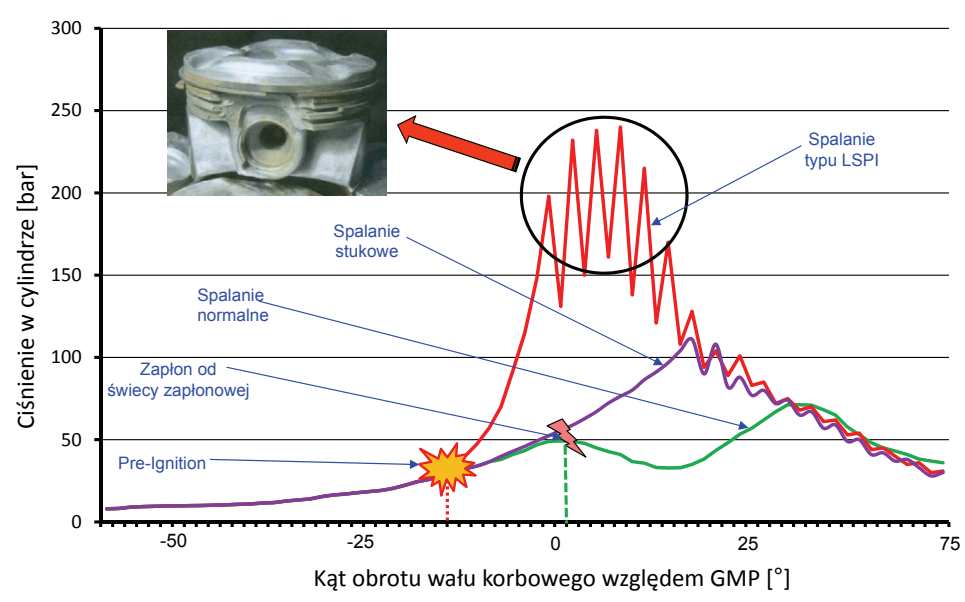

Rys. 1. Porównanie przebiegu ciśnienia w przypadku spalania normalnego, typowego spalania stukowego i spalania typu superstuk, występującego w przypadku LSPI

Fig. 1. Comparison of a conventional knocking with LSPI and subsequent super knocking and a cycle of normal combustion 


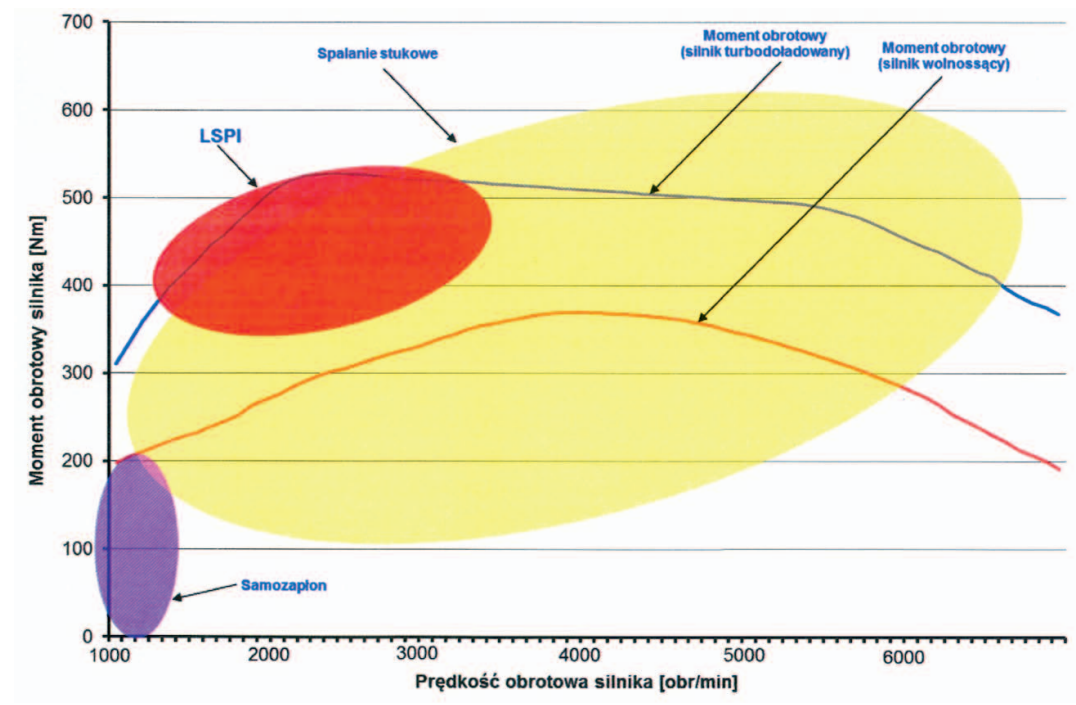

Rys. 2. Obszar występowania zjawiska LSPI na tle obszaru występowania typowego spalania stukowego

Fig. 2. The area arising from the LSPI phenomenon in comparison with the phenomenon of conventional knocking

W przeciwieństwie do typowego spalania stukowego zjawisko LSPI jest trudne do przewidzenia, a zatem jest to proces stochastyczny (losowy) występujący przed kontrolowanym iskrą zapłonem ładunku mieszanki paliwowo-powietrznej w silniku. Zjawisku LSPI nie można przeciwdziałać poprzez zmiany kąta wyprzedzenia zapłonu lub poprzez zwiększanie liczby oktanowej paliwa. W tym przypadku brak jest też korelacji pomiędzy LSPI a wielkością LOB (liczba oktanowa badawcza) i LOM (liczba oktanowa motorowa). Zatem spalanie stukowe oraz LSPI to dwa różne procesy nienormalnego spalania powstające na skutek różnie zainicjowanych i przebiegających zjawisk. Mechanizm powstawania zjawiska LSPI nie został dotychczas w pełni wyjaśniony. W przeciwieństwie do spalania stukowego obecnie nie ma jeszcze sposobu ani jednostki miary, które wyrażałyby wielkość zjawiska LSPI.

\section{Przedwczesny zapłon w zakresie małej prędkości obrotowej silnika doładowanego}

Zjawisko LSPI nasila się w miarę wzrostu mocy jednostkowej silników turbodoładowanych, a zatem coraz większego ciśnienia ich doładowania. Pomimo wielu prac badawczo-poznawczych przeprowadzonych w różnych ośrodkach badawczych na świecie dotychczas nie został, w sposób jednoznaczny, ustalony mechanizm powstawania LSPI, a co za tym idzie - sposób przeciwdziałania temu niebezpiecznemu zjawisku. Nieprzewidywalność wystąpienia LSPI czyni je zjawiskiem bardzo trudnym do odtworzenia w warunkach badań laboratoryjnych. Wiadomo, że LSPI jest bardzo skomplikowane, pojawia się na skutek złożonych powiązań i interakcji pomiędzy różnymi czynnikami, z których część nie została w pełni rozeznana, a część z nich zapewne nie jest dotychczas w ogóle rozpoznana. W związku z powyższym istnieje kilka teorii co do mechanizmu powstawania omawianego zjawiska i czynników na nie wpływających. Koncepcja najczęściej cytowana w literaturze zakłada, że najważniejszymi czynnikami mającymi wpływ na proces nienormalnego spalania typu LSPI jest konstrukcja silnika, warunki jego pracy i właściwości silnikowego oleju smarowego w powiązaniu z właściwościami paliwa (Magar et al., 2015; Döhler i Pritze, 2013; Welling et al., 2014). Badania przeprowadzone w ośrodku badawczym firmy Toyota, ale także firm Ford oraz GM wskazały na duże znaczenie rozpraszania w komorze spalania silnika kropelek smarowego oleju silnikowego, mogącego stanowić źródło powstania LSPI (Takeuchi et al., 2012; Dingle et al., 2014; Qi et al., 2014; Li et al., 2019). W silniku ZI z bezpośrednim wtryskiem paliwa strugi rozpylanego w komorach spalania paliwa omywają ścianki tulei cylindrowych, powodując rozcieńczanie pokrywającego je filmu smarowego oleju silnikowego. Powstała w ten sposób mieszanka oleju smarowego z paliwem na skutek zmniejszonej, względem samego oleju smarowego, lepkości oraz sił przylegania do powierzchni spływa i kumuluje się ponad pierwszym, górnym pierścieniem tłoka. Ponadto ilość mieszanki oleju smarowego z paliwem szybko rośnie powyżej pierścienia tłoka, który poruszając się w górę, w suwie sprężania, w kierunku GMP (górne martwe położenie) powoduje zgarnianie warstewki rozcieńczonego oleju z powierzchni tulei cylindrowej. W momencie osiągnięcia przez tłok GMP, na skutek sił bezwładności działających na coraz większą ilość skumulowanego nad pierścieniem rozcieńczonego oleju smarowego, następuje wypchnięcie kropelek tego oleju ze szczeliny pomiędzy tłokiem i ścianką tulei cylindrowej do komory spalania. W ten sposób rozproszone w komorze spalania krople szybko odparowują, a wokół nich tworzy się warstwa palnych par oleju i paliwa zmieszanego z powietrzem. Na skutek rosnącego ciśnienia i temperatury w komorze spalania silnika następuje spontaniczny, niekontrolowany, przedwczesny zapłon (rys. 3, 4a). Powstałe w ten sposób jądro płomienia powoduje zapłon otaczającej go, wytworzonej już w komorze spalania, mieszanki paliwowo-powietrznej, w której następuje gwałtowne rozprzestrzenianie się płomienia (rys. 4b). Na skutek bardzo szybko zwiększających się wartości temperatury i ciśnienia w komorze spalania następuje gwałtowny samozapłon całej pozostałej mieszanki w komorze spalania i powstaje zjawisko superstuku (rys. 4c).

Według obecnego stanu wiedzy silnikowy olej smarowy, a w szczególności uszlachetniające go dodatki na bazie metali, 

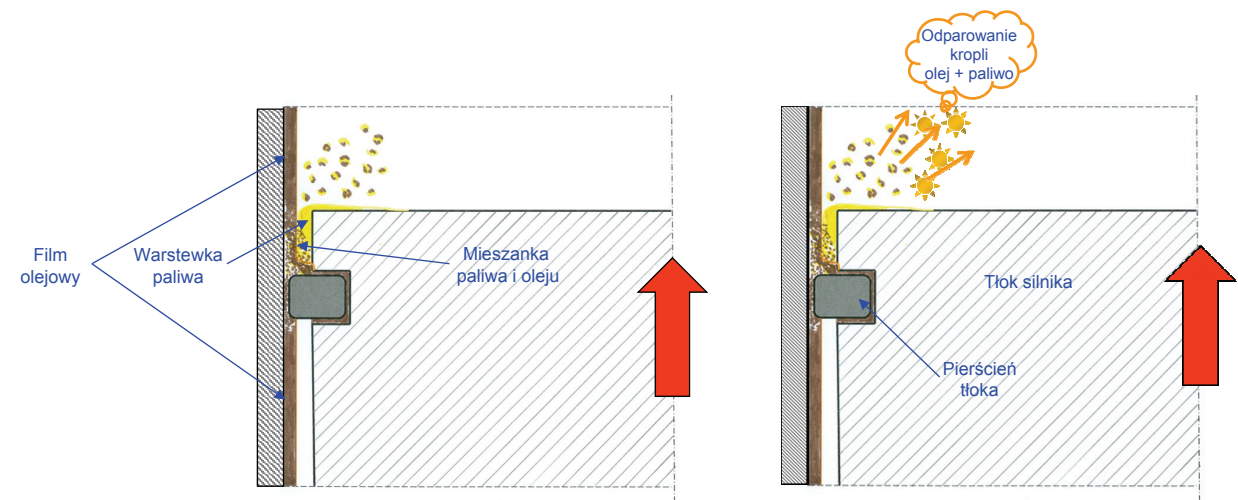

Rys. 3. Mechanizm przedostawania sie kropelek silnikowego oleju smarowego do komór spalania silnika

Fig. 3. Mechanism of entry of engine lubricating oil droplets into the engine combustion chambers
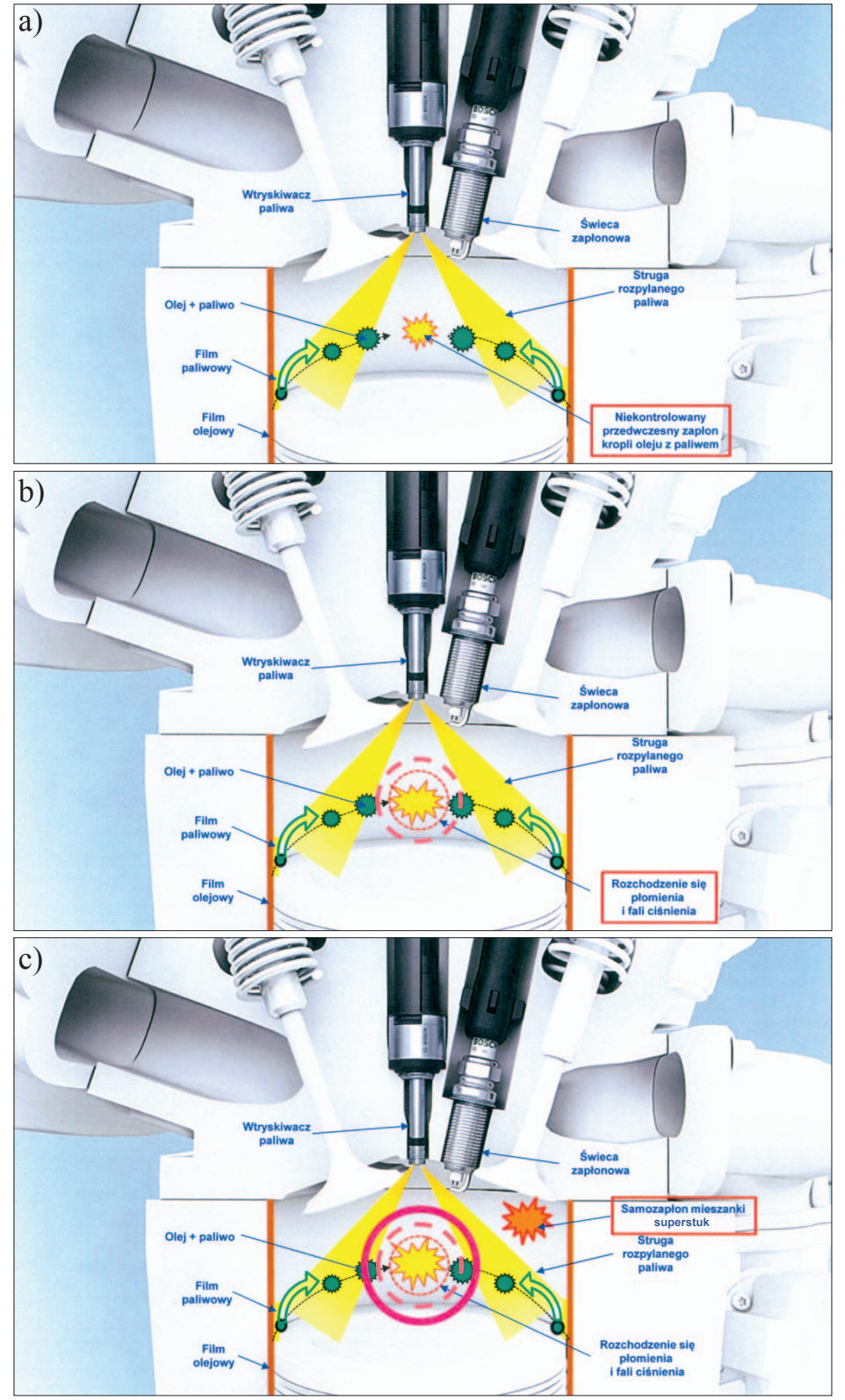

Rys. 4. Mechanizm powstawania superstuku na skutek LSPI;

a) przedwczesny zapłon, b) rozprzestrzenianie się płomienia (powstanie i rozchodzenie się fali rosnącego ciśnienia), c) samozapłon sprężonej mieszanki - wzbudzenie superstuku

Fig. 4 The mechanism of super knocking arising as a result of LSPI; a) pre-ignition, b) flame propagation (formation and propagation of increasing pressure waves), c) auto ignition of the compressed mixture - generating super knocking mają bardzo duży wpływ na powstawanie i rozwój zjawiska LSPI (Takeuchi et al., 2012; Yasueda et al., 2013; Spicher et al., 2016).

Wskazuje się tu przede wszystkim na dodatki detergentowe na bazie metali takich jak Ca czy Mg, które przeciwdziałają tworzeniu się osadów w silniku oraz neutralizują kwaśne produkty powstające w oleju smarowym na skutek przedostawania się do niego produktów spalania w silniku. Zawierają one $\mathrm{CaCO}_{3}$ lub $\mathrm{MgCO}_{3}$ stabilizowane przez rozpuszczalne w oleju grupy łańcuchów węglowodorowych. Według teorii zwanej $\mathrm{CaO}$-theory przedostające się do komory spalania silnika krople oleju smarowego spalają się w procesie dyfuzyjnym i następuje rozkład jądra $\mathrm{CaCO}_{3}$ na cząstki $\mathrm{CaO}$. Tak utworzone cząstki pozostają w komorze spalania aż do wymiany ładunku (resztkowe, pozostałościowe gazy ze spalania i EGR), a następnie w kolejnym suwie sprężania reagują z $\mathrm{CO}_{2}$. W tej egzotermicznej reakcji cząstki $\mathrm{CaCO}_{3}$ nagrzewają się do temperatury około $1000 \mathrm{~K} \mathrm{i}$ tworzą gorące miejsca aktywne, tzw. hot spots, inicjujące proces samozapłonu. Reakcja endotermicznego rozkładu $\mathrm{MgCO}_{3}$ zachodzi już w temperaturze około $870 \mathrm{~K}$ (Maitra et al., 2008). Dlatego też $\mathrm{MgCO}_{3}$ nie osiąga tak wysokiej wartości temperatury jak $\mathrm{CaCO}_{3}$, tj. około $1000 \mathrm{~K}$. W rezultacie cząstki zawierające $\mathrm{Mg}$ nie tworzą wystarczająco gorących hot spots, które mogą zainicjować proces przedwczesnego samozapłonu.

\section{Wpływ kompozycji silnikowego oleju smarowego na LSPI}

Dotychczas przeprowadzone badania, w różnych ośrodkach na całym świecie, jednoznacznie wskazują na duży wpływ silnikowego oleju smarowego na inicjowanie i rozwój nienormalnego spalania, w szczególności w wysoko doładowanych silnikach typu GDI (gasoline direct injection), spowodowanego zjawiskiem LSPI (Mayer et al., 2016; Clifford et al., 2018). Jednak wyniki wpływu na LSPI zarówno baz olejowych, jak i różnych składników 
pakietów uszlachetniających stosowanych w silnikowych olejach smarowych są często niespójne lub wręcz sprzeczne ze sobą, co wynika między innymi z różnych sposobów i warunków prowadzenia badań, pomiarów i ocen zjawiska LSPI. Badania LSPI prowadzone są zarówno na zmodyfikowanych stanowiskach typu ignition quality tester (IQT), jak i na specjalnie do tego celu zbudowanych, obecnie już uznanych, silnikowych stanowiskach badawczych opracowanych przez firmę Ford (Sequence IX Test) oraz GM. W przypadku tego pierwszego do testu jest wykorzystywany silnik Ford EcoBoost o objętości skokowej 2,0 $\mathrm{dm}^{3}$, a w przypadku drugiego - silnik Ecotec, także o objętości skokowej 2,0 dm .

Jakość (grupa) bazy olejowej oraz lepkość smarowego oleju silnikowego mają niewątpliwy wpływ na powstawanie zjawiska LSPI. Wyniki przeprowadzonych w tym zakresie badań w ośrodku badawczym firmy Infineum (Ritchie et al., 2016) wskazują na różne oceny wpływu bazy olejowej na zjawisko LSPI w zależności od zastosowanej metody (testu) badania (rys. 5).

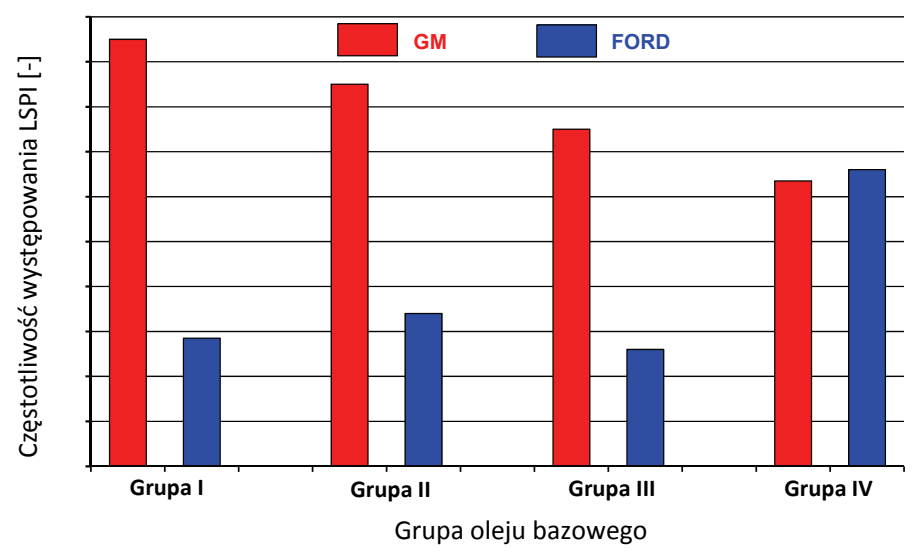

Rys. 5. Wpływ grupy pochodzenia oleju bazowego na częstotliwość występowania zjawiska LSPI (na podstawie badań firmy Infineum)

Fig. 5. Oil base stock effects on the frequency of LSPI

Jak widać na rysunku 5, częstotliwość występowania zjawiska LSPI w teście „GM” maleje wraz ze wzrostem jakości bazy olejowej. W przypadku oceny przeprowadzonej w teście „FORD” ocena jest zupełnie inna. Nie występuje tu tendencja zmniejszania częstotliwości występowania zjawiska LSPI w miarę poprawy jakości bazy olejowej, a baza olejowa grupy IV wykazuje największą tendencję do promowania zjawiska LSPI.

Znacznie większy wpływ na zjawisko LSPI ma skład dodatków uszlachetniających (w szczególności detergentowych) stosowanych do silnikowych olejów smarowych aniżeli sama baza olejowa. Największą rolę odgrywają w tym przypadku dodatki detergentowe zawierające wapń, który wyraźnie wpływa na zwiększenie częstotliwości występowania zjawiska LSPI.
W ośrodku badawczym koncernu BP (między innymi) przeprowadzono badania wpływu wapnia zawartego w trzech różnych typach dodatków detergentowych w warunkach zimnego lub rozgrzanego silnika na częstotliwość występowania LSPI. Uzyskane wyniki jednoznacznie dowodzą znacznego wpływu wapnia na zwiększenie częstotliwości występowania zjawiska LSPI, zwłaszcza w przypadku badań prowadzonych na zimnym silniku (rys. 6). Stwierdzono też, że zawarty w oleju smarowym sód wspomaga działanie wapnia w wywoływaniu LSPI.

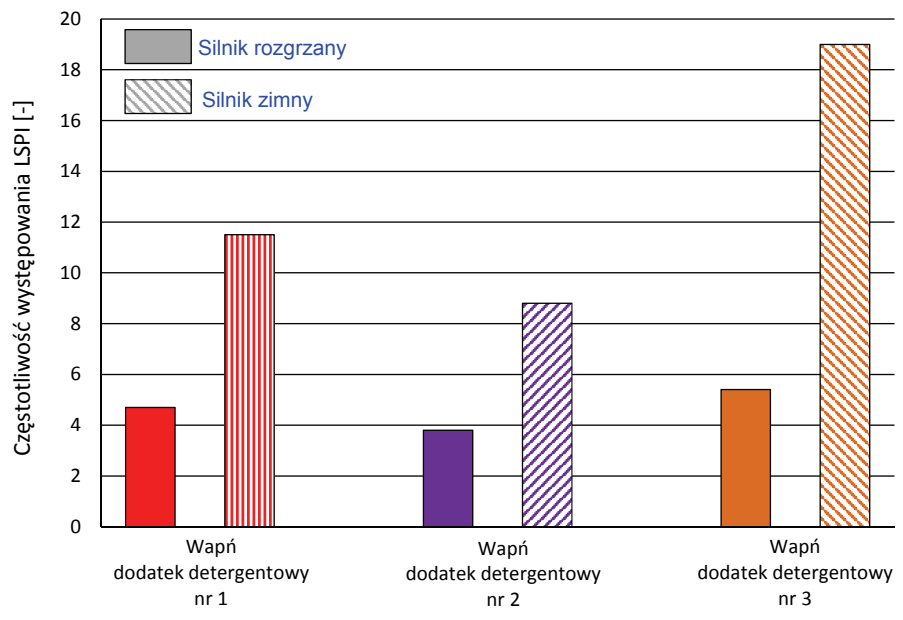

Rys. 6. Wpływ różnych dodatków detergentowych zawierających wapń na częstotliwość występowania zjawiska LSPI (na podstawie badań BP)

Fig. 6. Influence of calcium containing detergent additives on the frequency of LSPI

Przeprowadzono też badania wpływu ilości trzech typów związków wapnia zawartych w różnych dodatkach detergentowych w porównaniu $\mathrm{z}$ dodatkiem detergentowym zawierającym Mg na częstotliwość występowania LSPI (rys. 7).

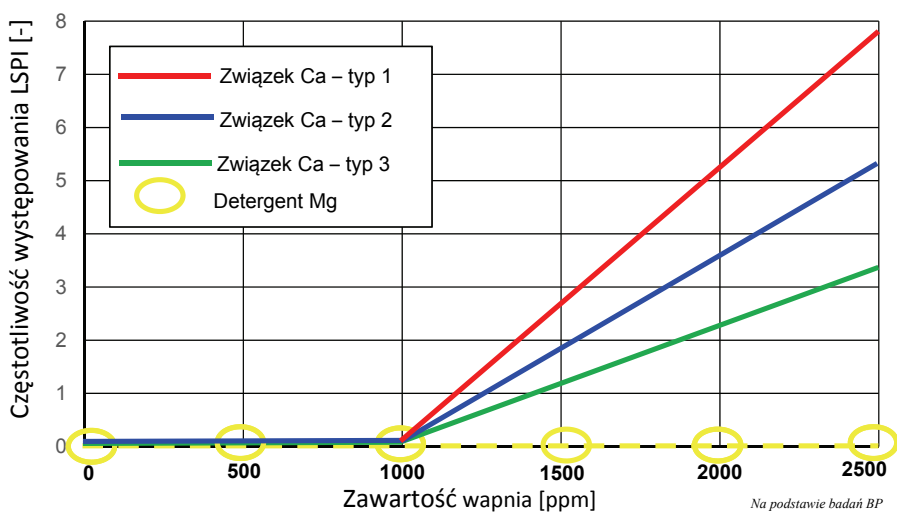

Rys. 7. Wpływ różnej zawartości trzech typów związków wapnia i jednego związku magnezu w dodatkach detergentowych na częstotliwość występowania zjawiska LSPI (na podstawie badań BP)

Fig. 7. Impact of different content of the three various types of calcium compounds and one magnesium compound in detergent additives on the frequency of LSPI 
Jak widać na rysunku 7, niezależnie od związku, w jakim występuje Ca, powyżej zawartości 1000 ppm silnie wzmacnia on tendencję silnikowego oleju smarowego do zwiększania częstotliwości występowania zjawiska LSPI. Dodatek detergentowy zawierający $\mathrm{Mg}$, niezależnie od poziomu jego zawartości, w ogóle nie wpływa na zjawisko LSPI. Jak stwierdzono też w badaniach przeprowadzonych między innymi w ośrodkach badawczych firm Infineum, Chevron i BP, występowaniu zjawiska LSPI sprzyjają również zawarte w smarowym oleju silnikowym $\mathrm{Fe}$ i $\mathrm{Cu}$ oraz procesy degradacji silnikowego oleju smarowego.

W silnikowych olejach smarowych znajdują się też składniki przeciwdziałające występowaniu LSPI. Najskuteczniejszym $\mathrm{z}$ nich jest fosfor, zawarty $\mathrm{w}$ do niedawna szeroko stosowanym dodatku przeciwzużyciowym opartym na cynku i fosforze znanym jako ZDDP (zinc dialkyldithiophosphate). W Infineum przeprowadzono badania, w których w oleju smarowym zwiększano zawartość fosforu w ZDDP od 0,05\% aż do 0,225\% i obserwowano jego wpływ na częstotliwość występowania LSPI (rys. 8).

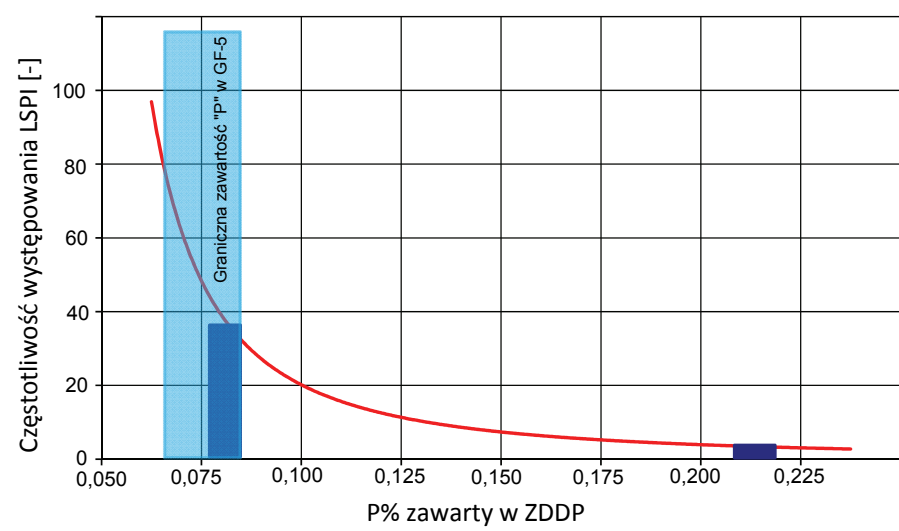

Rys. 8. Wpływ fosforu zawartego w ZDDP na występowanie zjawiska LSPI (na podstawie badań firmy Infineum)

Fig. 8. Impact of phosphorus in ZDDP on the frequency of LSPI

Wyniki przedstawione na rysunku 8 wykazują, że zwiększenie zawartości fosforu w smarowym oleju silnikowym wpływa w sposób wykładniczy na zmniejszanie częstotliwości występowania zjawiska LSPI. Przy zawartości fosforu w silnikowym oleju smarowym na poziomie $0,150 \%$ następuje zmniejszenie częstotliwości występowania LSPI o ponad 90\%. Jednak, jak wiadomo, fosfor i popiół zawarty w ZDDP bardzo niekorzystnie oddziałują na trwałość reaktorów katalitycznych gazów spalinowych wydalanych z silników. W konsekwencji wymusiło to wprowadzenie silnikowych olejów smarowych typu low SAPS, o małej zawartości siarki, fosforu i popiołów siarczanowych (Urzędowska i Stępień, 2012a, 2012b). Ustalono też, że zawarty w modyfikatorze tarcia typu MoDTC (molibdenoorganiczny modyfikator tarcia typu ditiokarbaminian molibdenu) molibden skutecznie przeciwdziała powstawaniu LSPI.
Przeprowadzone dotychczas badania wykorzystania szeroko stosowanych przeciwutleniaczy typu: alkilowana difenyloamina, podstawione alkilofenole i siarkowane estry jako związków przeciwdziałających powstawaniu LSPI zakończyły się niepowodzeniem.

\section{Podsumowanie}

Rozwój tłokowych silników spalinowych z zapłonem iskrowym poprzez tzw. downsizing umożliwia poprawę ich sprawności ogólnej, a zatem także zmniejszenie jednostkowego zużycia paliwa i ograniczenie emisji $\mathrm{CO}_{2}$. Dalsza poprawa sprawności silników poprzez downsizing wiąże się ze zwiększaniem ciśnienia i temperatury ładunku sprężanego w komorach spalania silnika, co prowadzi do występowania przedwczesnego, niekontrolowanego zapłonu mieszanki paliwowo-powietrznej (LSPI - low speed pre-ignition) i w konsekwencji - nienormalnego procesu spalania, podczas którego występuje zjawisko tzw. superstuku, mogące doprowadzić do zniszczenia silnika. LSPI jest stochastycznym, przedwczesnym samozapłonem paliwa występującym przed normalnym zapłonem, zainicjowanym przez iskrę świecy zapłonowej. Zmiana kąta wyprzedzenia zapłonu nie zapobiega powstawaniu zjawiska LSPI. Brak też korelacji pomiędzy LSPI a LOB i LOM.

Najbardziej prawdopodobna teoria mechanizmu powstawania LSPI zakłada wypychanie przez pierścienie tłoka ze szczeliny pomiędzy tłokiem i tuleją cylindrową kropelek silnikowego oleju smarowego rozcieńczonego benzyną, a następnie ich niekontrolowany, nieprzewidywalny samozapłon na skutek zwiększającego się ciśnienia i temperatury w komorze spalania silnika. Czynnikami mającymi wpływ na bardzo skomplikowany proces zainicjowania i rozwoju zjawiska LSPI są interakcje zachodzące pomiędzy silnikowym olejem smarowym, paliwem, konstrukcją silnika oraz warunkami jego pracy. Z uwagi na stochastyczny charakter występowania zjawiska LSPI obecnie jedynym sposobem oceny jego występowania i zagrożeń, jakie powoduje, jest odpowiedni, przeznaczony do tego celu test silnikowy (Ford, GM). Dotychczas przeprowadzone badania jednoznacznie potwierdziły, że smarowy olej silnikowy ma duży wpływ na inicjowanie i rozwój nienormalnego spalania, w szczególności w wysoko doładowanych silnikach typu GDI (gasoline direct injection), spowodowanego zjawiskiem LSPI. Wapń zawarty w dodatkach detergentowych do smarowego oleju silnikowego, niezależnie od związku, w jakim występuje, sprzyja powstawaniu zjawiska LSPI. W miarę wzrostu zawartości wapnia w oleju smarowym zwiększa się częstotliwość występowania LSPI. Sód w oleju smarowym wspomaga działanie wapnia w wywoływaniu LSPI. Z kolei fosfor zawarty w dodatku przeciwzużyciowym typu ZDDP 
smarowego oleju silnikowego bardzo skutecznie przeciwdziała występowaniu LSPI. W związku z tym wskazuje się na możliwość zwiększenia zawartości fosforu w przyszłych generacjach silnikowych olejów smarowych, co jest sprzeczne z obecnym ograniczaniem zawartości ZDDP ze względu na szkodliwe oddziaływanie fosforu na katalizatory i DPF (oleje smarowe low SAPS, o małej zawartości siarki, fosforu i popiołów siarczanowych).

Konieczność przeciwdziałania LSPI wymusza wprowadzanie do nowych specyfikacji smarowych olejów silnikowych dodatkowego testu silnikowego oceniającego olej pod kątem wpływu na to zjawisko. Formulacje przyszłych generacji silnikowych olejów smarowych będą musiały uwzględniać ich wpływ na inicjowanie i częstotliwość powstawania LSPI.

\section{Literatura}

Clifford M., Briggs T., Anderson G., 2018. Combined Fuel and Lubricant Effects on Low Speed Pre-Ignition. SAE Technical Papers, 2018-01-1669.

Dahnz C., Spicher U., 2010. Irregular combustion in supercharged spark ignition engines: Pre-ignition and other phenomena. International Journal of Engine Research, 11(6): 485-498.

Dingle S.F., Cairns A., Zhao H. et al., 2014. Lubricant Induced Pre-Ignition in an Optical SI Engine. SAE Technical Papers, 2014-01-1222.

Döhler A., Pritze S., 2013. A contribution to better understanding the pre-ignition phenomenon in highly supercharged internal combustion engines with direct fuel injection. IAV Congress „Knocking in Gasoline Engines”, Berlin.

Fraser N., Blaxill H., Lumsden G., Bassett M., 2009. Challenges for Increased Efficiency through Gasoline Engine Downsizing. SAE International Journal of Engines, 2(1), 991-1008. DOI: 10.4271/2009-01-1053.

Li R., Xu B., Qi Y., 2019. Research on Mechanism of Low Speed Pre-Ignition and Knock Process in Boosted Direct Injection Spark Ignition Gasoline Engines. IOP Conf. Series: Journal of Physics: Conf. Series, 1176: 052069. DOI: 10.1088/1742-6596/1176/5/052069.

Magar M., Spicher U., Palaveev S., Gohl M. et al., 2015. Experimental studies on the occurrence of low-speed pre-ignition in turbocharged GDI engines. SAE report, 2015-01-0753.

Maitra S., Chakrabarty N., Pramanik J., 2008. Decomposition kinetics of alkaline earth carbonates by integral approximation method. Ceramica, 54(331): 268-272.

Mayer M., Hofmann P., Geringer B., Williams J., Moss J., Kapus P., 2016. Influence of Different Oil Properties on Low Speed PreIgnition in Turbocharged Direct Injection Spark Ignition Engines. SAE International, 2016-01-0718.
Qi Y.L., Xu Y.Q., Wang Z. et al., 2014. The Effect of Oil Intrusion on Super Knock in Gasoline Engine. SAE Technical Papers, 2014-01-1224.

Ritchie A., Boese D., Young A.W., 2016. Controlling Low-Speed PreIgnition in Modern Automotive Equipment Part 3: Identification of Key Additive Component Types and Other Lubricant Composition Effects on Low-Speed Pre-Ignition. SAE Technical Papers, 2016-01-0717.

Shahed S.M., Bauer K.H., 2009. Parametric Studies of the Impact of Turbocharging on Gasoline Engine Downsizing. SAE International Journal of Engines, 2(1), 1347-1358. DOI: 10.4271/2009-01-1472.

Spicher U., Gohl M., Magar M., Hadler J., 2016. The Role of Engine Oil in Low-speed Pre-Ignition. MTZ worldwide, 77(1): 60-63.

Takeuchi K., Fujimoto K., Hirano S. et al., 2012. Investigation of Engine Oil Effect on Abnormal Combustion in Turbocharged Direct Injection-Spark Ignition Engines. Development \& Learning in Organizations, 5(3): 1017-1024.

Turner J.W.G., Popplewell A., Patel R., Johnson T.R., Darnton N.J., Richardson S. et. al., 2014. Ultra Boost for Economy: Extending the Limits of Extreme Engine Downsizing. SAE International Journal of Engines, 7(1), 387-417. DOI: 10.4271/2014-01-1185.

Urzędowska W., Stępień Z., 2012a. Oddziaływanie paliwa na zmiany właściwości użytkowych oleju smarowego w silniku z ZI typu FlexFuel. Nafta-Gaz, 6: 377-387.

Urzędowska W., Stępień Z., 2012b. Wybrane zagadnienia dotyczące zmian właściwości silnikowego oleju smarowego w eksploatacji. Nafta-Gaz, 12: 1102-1110.

Wang Z., Long Y., Wang J., 2015. Research progress of pre-ignition and super-knock in boost gasoline engine. Journal of Automotive Safety \& Energy, 6(1): 17-29.

Welling O., Moss J., Williams J., Collings N. et al., 2014. Measuring the impact of engine oils and fuels on low-speed pre-ignition in downsized engines. SAE report, 2014-01-1219.

Yasueda S., Takasaki K., Tajima H., 2013. Abnormal Combustion caused by Lubricating Oil in High BMEP Gas Engines. $M T Z$ industrial, Special Edition MTZ: 34-39.

Zahdeh A., Rothenberger P., Nguyen W. et al., 2011. Fundamental Approach to Investigate Pre-Ignition in Boostede SI Engines. SAE International Journal of Engines, 4(1): 246-273.

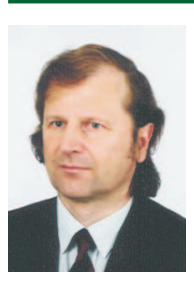

Dr hab. inż. Zbigniew STĘPIEŃ, prof. INiG - PIB Kierownik Zakładu Oceny Właściwości Eksploatacyjnych, kierownik Pracowni Badań Silnikowych i Trybologicznych Zakładu Oceny Właściwości Eksploatacyjnych Instytut Nafty i Gazu - Państwowy Instytut Badawczy ul. Lubicz 25 A, 31-503 Kraków E-mail: zbigniew.stepien@inig.pl 